\title{
Benthic scavengers and predators of jellyfish, material for a review
}

\author{
Ron M. L. ATES* \\ Govert Flinckstraat 19, 1506LL Zaandam, the Netherlands \\ Received 6 April 2016; Accepted 18 November 2016 Responsible Editor: Dhugal Lindsay
}

\begin{abstract}
Instances of predation and scavenging of jellyfish (pelagic Scyphozoa, Hydrozoa and Ctenophora) by benthic invertebrates are reviewed and presented. Sea anemones and decapod crabs are widespread as well as common predators or scavengers of jellyfish. Dead or dying jellyfish are also preyed upon by species of Echinodermata.
\end{abstract}

Key words: Actiniaria, Decapoda, Echinodermata, predation, scavenging, Scyphozoa, Hydrozoa, Ctenophora

Over the past decades the interaction between jellyfish and other animals received some attention (e.g. Arai 2005). Evidence had become available countering the previous prejudiced ideas about the negligible number of animal species preying on jellyfish. Nevertheless, jellyfish continue to be depicted occasionally (see Arai 2005 for examples) as dead ends in the food chains of the sea and/or as a rare source of food for predators (e.g. Condon et al. 2011), despite an increasing number of species of fishes (Redeke 1911, Luttenberger 1981, Gorelova \& Grudtsev 1986, Kelley 1987, Ates 1988, Arai 1988, Zann 1988: 208, Cerqueira \& Haimovici 1990, Hall 1992, Harbison 1993, Massuti et al. 1998, Purcell \& Arai 2001, Bonaldo et al. 2004, Arai 2005, Orsi Relini et al. 2010a, Orsi Relini et al. 2010b, Chaves et al. 2010, Thaler 2012, Cardona et al. 2012, Milisenda et al. 2014, Battaglia et al. 2014, Sweetman et al. 2014, Dias \& Almeida 2015), birds, reptiles and mammals (Dathe 1989, Ates 1991, Gronert 1992, Shiomi \& Ogi 1992, Bell 1996, Zonfrillo 1997, Peglow 1998, Corsi 2000, Arai 2005, Suazo 2008, Cardona et al. 2012, Jarman et al. 2013, Melville 2013, Jones \& Seminoff 2013), other cnidarians and ctenophores (Purcell 1991, Bamstedt et al. 1997, Bayha et al. 2012), polychaetes, helminths, molluscs and arthropods (Arai 2005, Stoner \& Layman 2015) known to take them as prey.

Invertebrate species belonging to other groups have infrequently been mentioned as predators or scavengers of jellyfish. However, scuba-divers may encounter benthic animals consuming live or dead jellyfish on a regular basis. In Table 1 all records of sea anemones, corals, decapod crabs and echinoderms consuming live or dead jellyfish, known to me from

\footnotetext{
*Corresponding author: Ron M. L. Ates; E-mail, pseudocorynactis@ zonnet.nl
}

the literature or otherwise, are listed.

Jellyfish (pelagic Scyphozoa, Hydrozoa and Ctenophora) easily fall victim to benthic invertebrate predators such as sea anemones. For about thirty years I have been able to observe for example Metridium senile taking jellyfish, mainly Aurelia aurita, Cyanea lamarckii and Pleurobrachia pileus, in considerable numbers in the Oosterschelde estuary, southwestern Netherlands (unpublished observations). Although the predation and the scavenging of jellyfish appears not to be limited geographically, most records in Table 1 are from eastern Atlantic waters, doubtlessly because I am more familiar with the grey literature in Europe.

The predominant prey mentioned in Table 1 taken by sea anemones, decapod crabs and echinoderms alike appear to be species of Scyphozoa. Observations of Pleurobrachia, Neoturris, Eutonina, Eucheilota and even scyphozoan ephyrae (see Table 1) make clear that this predation is however not size-limited. As the consumption time of the larger jellyfish exceeds several times that of the mostly much smaller hydrozoans and ctenophores, the likelihood of encountering Scyphozoa being consumed is much higher.

Few records in Table 1 go beyond the mere noting of the actual consumption of the jellyfish. In fact many of them have a casual or even tentative character. For patterns to be recognized more detailed observations need to be published. Hopefully future observers will publish more data pertaining to their observations of jellyfish being eaten. Berryman (1984) suggested that the predation by the sea anemone Sagartiogeton laceratus on A. aurita may become noteworthy when swarms of jellyfish are locally concentrated due to currents and topography. However, when scuba-diving, predation by sea anemones sensu latu upon jellyfish may be observed in each and every location where the two occur together. When 
Table 1. Benthic Cnidaria, decapod Crustacea and Echinodermata recorded to have consumed live or dead jellyfish.

\begin{tabular}{|c|c|c|c|}
\hline PREDATOR OR SCAVENGER & PREY & LOCALITY & SOURCE \\
\hline \multicolumn{4}{|l|}{ Cnidaria Actiniaria } \\
\hline Actinia equina (Linnaeus, 1758) & Pleurobrachia pileus (Müller, 1776) & North Sea & Den Hartog 1963 \\
\hline A. equina & Cyanea lamarckii Péron \& Lesueur, 1810 & Channel Islands, England & S. Daly in: Wood 2013 \\
\hline Actinia tenebrosa Farquhar, 1898 & Scyphozoa & Australian waters & Ayre 1984 \\
\hline Actinoporus elegans Duchassaing, 1850 & Aurelia? & Curaçao, Caribbean & Van der Vlugt $1981^{*}$ \\
\hline Actinostola callosa (Verrill, 1882) & $\begin{array}{l}\text { Periphylla periphylla (Péron \& Lesueur, } \\
\text { 1810) }\end{array}$ & Norwegian waters & Jarms \& Tiemann 2004 \\
\hline $\begin{array}{l}\text { Anthopleura elegantissima (Brandt, } \\
\text { 1835) }\end{array}$ & Velella velella (Linnaeus, 1758) & northeastern Pacific & Francis 1973; Wertheim 1984 \\
\hline Diadumene cincta Stephenson, 1925 & Eutonina indicans (Romanes, 1876) & Oosterschelde, Netherlands & pers. comm. M. Vestjens 2002 \\
\hline Diadumene leucolena (Verrill, 1866) & Chrysaora quinquecirrha (DeSor, 1848) & western Atlantic & $\begin{array}{l}\text { Cargo \& Schultz 1967*; Cones \& } \\
\quad \text { Haven } 1969\end{array}$ \\
\hline Metridium farcimen (Brandt, 1835) & Cyanea capillata (Linnaeus, 1758) & northeastern Pacific & pers. comm. R. Harbo 2012 \\
\hline Metridium senile (Linnaeus, 1767) & $\begin{array}{l}\text { Aequorea victoria (Murbach \& Shearer, } \\
\text { 1902) }\end{array}$ & northeastern Pacific & pers. comm. C.E. Mills 2000 \\
\hline M. senile & hydroid fragments & western Atlantic & Sebens \& Koehl 1984 \\
\hline M. senile & Aurelia aurita (Linnaeus, 1758) & Grevelingen, Netherlands & this paper, see photo B \\
\hline M. senile & $\begin{array}{l}\text { A. aurita, P. pileus, Chrysaora hysoscella } \\
\text { (Linnaeus, 1767) }\end{array}$ & Oosterschelde, Netherlands & Ates 2002 \\
\hline M. senile & P. pileus & North Sea & Greve $1972^{*}$ \\
\hline Paraphelliactis pabista Dunn, 1982 & medusae? & northeastern Pacific & Fautin 1982 \\
\hline Sagartia sp. & P. pileus & North Sea & Greve $1972 *$ \\
\hline Sagartia elegans (Dalyell, 1848) & C. hysoscella & Oosterschelde, Netherlands & this paper, see photo $\mathrm{C}$ \\
\hline $\begin{array}{l}\text { Sagartia troglodytes (Price in John- } \\
\text { ston, 1847) }\end{array}$ & A. aurita, C. lamarckii, C. hysoscella & Oosterschelde, Netherlands & Ates 2002 \\
\hline S. troglodytes & E. indicans & Oosterschelde, Netherlands & Ates 2014 \\
\hline Sagartiogeton laceratus (Dalyell, 1848) & A. aurita & North Sea & Berryman 1984 \\
\hline Sagartiogeton undatus (Müller, 1788) & Aequorea vitrina Gosse, 1853 & Grevelingen, Netherlands & this paper, see photo $\mathrm{D}$ \\
\hline S. undatus & cf. Eucheilota & Oosterschelde, Netherlands & pers. obs. July 2007 \\
\hline Urticina lofotensis (?) & $\begin{array}{l}\text { Aurelia labiata Chamisso \& Eysenhardt, } \\
\text { 1821, Phacellophora camtschatica } \\
\text { Brandt, } 1835\end{array}$ & $?$ & pers. comm. P. Lovejoy Sept. 2000 \\
\hline Urticina felina (Linnaeus, 1761) & $\begin{array}{l}\text { Rhizostoma pulmo (Macri, 1778), } P \text {. } \\
\text { pileus }\end{array}$ & North Sea & Den Hartog 1963 \\
\hline U. felina & P.pileus & North Sea & Greve $1972 *$ \\
\hline U. felina & jellyfish (Aurelia ?) & Scottish waters & Wood 2005 \\
\hline U. felina & A. aurita, C. lamarckii, C. hysoscella & Oosterschelde, Netherlands & Ates 2002 \\
\hline U. felina & C. hysoscella & North Sea & Schwanitz, in Jarms \& Tiemann 2004 \\
\hline U. felina & A. aurita & southwestern Ireland & pers. comm. W. Northway, May 2011 \\
\hline Urticinopsis antarcticus (Verrill, 1922) & jellyfish & Antarctic & Dayton et al. 1974 \\
\hline U. antarcticus & Desmonema sp. & Antarctic & Conniff 2000 \\
\hline sea anemone & Mastigias? & Lake Kakaban, Indonesia & this paper, see photo E \\
\hline $\begin{array}{l}\text { Entacmaea(?) medusivora Fautin \& } \\
\quad \text { Fitt, } 1991\end{array}$ & $\begin{array}{l}\text { Mastigias papua (Lesson, 1830), A. aurita, } \\
\text { Cassiopea ornata Haeckel, } 1880\end{array}$ & Lake Kakaban, Indonesia & Hoeksema et al. 2014 \\
\hline sea anemones & М. рариа & Palau, western Pacific & Hamner 1982 \\
\hline $\begin{array}{l}\text { Aiptasia pulchella }(?)=\text { E.(?) medu- } \\
\quad \text { sivora }\end{array}$ & М. рариа & Palau, western Pacific & $\begin{array}{l}\text { Hamner \& Hauri 1981; Fautin \& } \\
\text { Fitt } 1991\end{array}$ \\
\hline sea anemones & A. aurita ephyrae & Waddenzee, Netherlands & Swennen $1956^{*}$ \\
\hline sea anemone & Nemopilema nomurai Kishinouye, 1922 & Sea of Japan & Yamamoto et al. 2008 \\
\hline \multicolumn{4}{|l|}{ Cnidaria other than Actiniaria } \\
\hline Alcyonium digitatum Linnaeus, 1758 & P. pileus & North Sea & Greve $1972^{*}$ \\
\hline Cerianthus lloydii Gosse, 1859 & cf Neoturris pileata & Scottish waters & this paper, see photo A \\
\hline Fungia scruposa Klunzinger, 1879 & A. aurita & Red Sea & Alamaru et al. 2009 \\
\hline Tubularia sp. & Lensia sp. & $?$ & Mackie 1966 \\
\hline Tubularia larynx Ellis \& Solander, 1786 & gelatinous plankton & Irish Sea & Gili et al. 1996 \\
\hline
\end{tabular}


Table 1. Continued.

\begin{tabular}{|c|c|c|c|}
\hline PREDATOR OR SCAVENGER & PREY & LOCALITY & SOURCE \\
\hline \multicolumn{4}{|l|}{ Crustacea Decapoda } \\
\hline Aristeomorpha foliacea (Risso, 1827) & Siphonophora & NW-Australia & Rainer 1992 \\
\hline Aristeus virilis (Bate, 1881) & Siphonophora & NW-Australia & Rainer 1992 \\
\hline Callinectes sapidus (Rathbun, 1896) & $\begin{array}{l}\text { C. capillata, Stomolophus meleagris } \\
\text { (Agassiz, 1862) }\end{array}$ & Gulf of Mexico & Farr 1978 \\
\hline Cancer pagurus Linnaeus, 1758 & A. aurita & North Sea & Steinich 1973 \\
\hline Cancer sp. & Linuche sp. & Caribbean & Larson 1991 \\
\hline Carcinus maenas (Linnaeus, 1758) & P. pileus & North Sea & Greve 1972; Esser et al. 2004* \\
\hline C. maenas & A. aurita & Kattegat & Rasmussen 1973 \\
\hline C. maenas & A. aurita & Baltic Sea & Lauckner 1980 \\
\hline Crangon crangon (Linnaeus, 1758) & P. pileus & North Sea & Greve 1972*; Esser et al. 2004* \\
\hline Chorilia longipes Dana, 1852 & C. capillata & northeastern Pacific & Harbo 2011 \\
\hline Galathea squamifera Leach, 1814 & P. pileus & North Sea & Greve $1972 *$ \\
\hline Haliporoides sibogae (De Man, 1907) & Siphonophora & NW-Australia & Rainer 1992 \\
\hline Heterocarpus sibogae De Man, 1917 & Siphonophora & NW-Australia & Rainer 1992 \\
\hline $\begin{array}{l}\text { Heterocarpus woodmasoni Alcock, } \\
1901\end{array}$ & Siphonophora & NW-Australia & Rainer 1992 \\
\hline Homarus gammarus (Linnaeus, 1758) & A. aurita & Grevelingen, Netherlands & pers. comm. J. Bakker June 2013 \\
\hline Hyas araneus (Linnaeus, 1758) & C. capillata & Scottish waters & Ates \& Hoyinck 2012 \\
\hline H. araneus & A. aurita & Scottish waters & pers. comm. W. Northway May 2011 \\
\hline Jasus lalandii (Milne-Edwards, 1837) & hydromedusae & $?$ & Williamson, in Thomas $1963^{*}$ \\
\hline Liocarcinus depurator (Linnaeus, 1758) & C. capillata & Scottish waters & pers. comm. W. Northway Sept 2013 \\
\hline Menippe mercenaria (Say, 1818) & Stomolophus & Gulf of Mexico & Powell \& Gunter 1968 \\
\hline Munida rugosa (Fabricius, 1775) & A. aurita & Scottish waters & Naylor 2011 \\
\hline Necora puber (Linnaeus, 1767) & C. lamarckii & Oosterschelde, Netherlands & this paper, see photo $\mathrm{F}$ \\
\hline N.puber & A. aurita & Scottish waters & pers. comm. W. Northway Sept 2013 \\
\hline Ocypode quadrata (Fabricius, 1787) & Physalia physalis (Linnaeus, 1758) & Gulf of Mexico & Phillips et al. 1969 \\
\hline Pagurus anachoretus Risso, 1827 & Pelagia noctiluca (Forskål, 1775) & Mgar-Ix-Ieni, Gozo, Malta & this paper, see photo $\mathrm{G}$ \\
\hline Pagurus bernhardus (Linnaeus, 1758) & P. pileus & North Sea & Greve 1972*; Esser et al. 2004* \\
\hline P. bernhardus & A. aurita & Scottish waters & $\begin{array}{l}\text { Ates \& Hoyinck 2012; this paper, } \\
\text { see photo H }\end{array}$ \\
\hline P. bernhardus & C. capillata & Scottish waters & pers. comm. W. Northway Sept 2013 \\
\hline $\begin{array}{l}\text { Pagurus floridanus (Benedict, 1892), } \\
\quad \text { Pagurus pollicaris Say, } 1817\end{array}$ & Cyanea, Stomolophus & Gulf of Mexico & Phillips et al. $1969^{*}$ \\
\hline Portunus holsatus Fabricius, 1798 & P. pileus & North Sea & Greve $1972 *$ \\
\hline $\begin{array}{l}\text { Plesiopenaeus edwardsianus (Johnson, } \\
\text { 1868) }\end{array}$ & Siphonophora & NW-Australia & Rainer 1992 \\
\hline Pugettia producta (Randall, 1840) & jellyfish & northeastern Pacific & pers. comm A. Lamb 2012 \\
\hline Scyphax ornatus Dana, 1853 & Physalia, A. aurita, Velella & New Zealand intertidal & Quilter 1987 \\
\hline \multicolumn{4}{|l|}{ Crustacea other than Decapoda } \\
\hline Balanus eburneus Gould, 1841 & C. quinquecirrha ephyrae & western Atlantic & Cones \& Haven 1969 \\
\hline $\begin{array}{l}\text { Orchomenella obtusa (Sars, 1891), } \\
\text { Munida tenuimana Sars, 1872, } \\
\text { decapod shrimps }\end{array}$ & P. periphylla, C. capillata & Norwegian waters & Sweetman et al. 2014 \\
\hline \multicolumn{4}{|l|}{ Echinodermata } \\
\hline Asterias rubens Linnaeus, 1758 & C. capillata & Norwegian waters & Moen \& Svensen 2000 \\
\hline A. rubens & A. aurita & Scottish waters & Ates \& Hoyinck 2012 \\
\hline Ophiocomina nigra (Abildgaard, 1789) & A. aurita & Scottish waters & Ates \& Hoyinck 2012 \\
\hline Ophiothrix fragilis (Albildgaard, 1789) & A. aurita & Oosterschelde, Netherlands & Ates 2002 \\
\hline O. fragilis & A. aurita & Scottish waters & Ates \& Hoyinck 2012 \\
\hline seastar (Anseropoda?) & jellyfish & California & Wu 1998 \\
\hline $\begin{array}{l}\text { Strongylocentrotus franciscanus } \\
\quad \text { (Agassiz, 1863) }\end{array}$ & jellyfish & northeastern Pacific & pers. comm. A. Lamb 2012 \\
\hline ophiurids & Aurelia limbata (Brandt, 1835) & Sea of Japan & Miyake et al. 2002 \\
\hline
\end{tabular}

* aquarium observation 


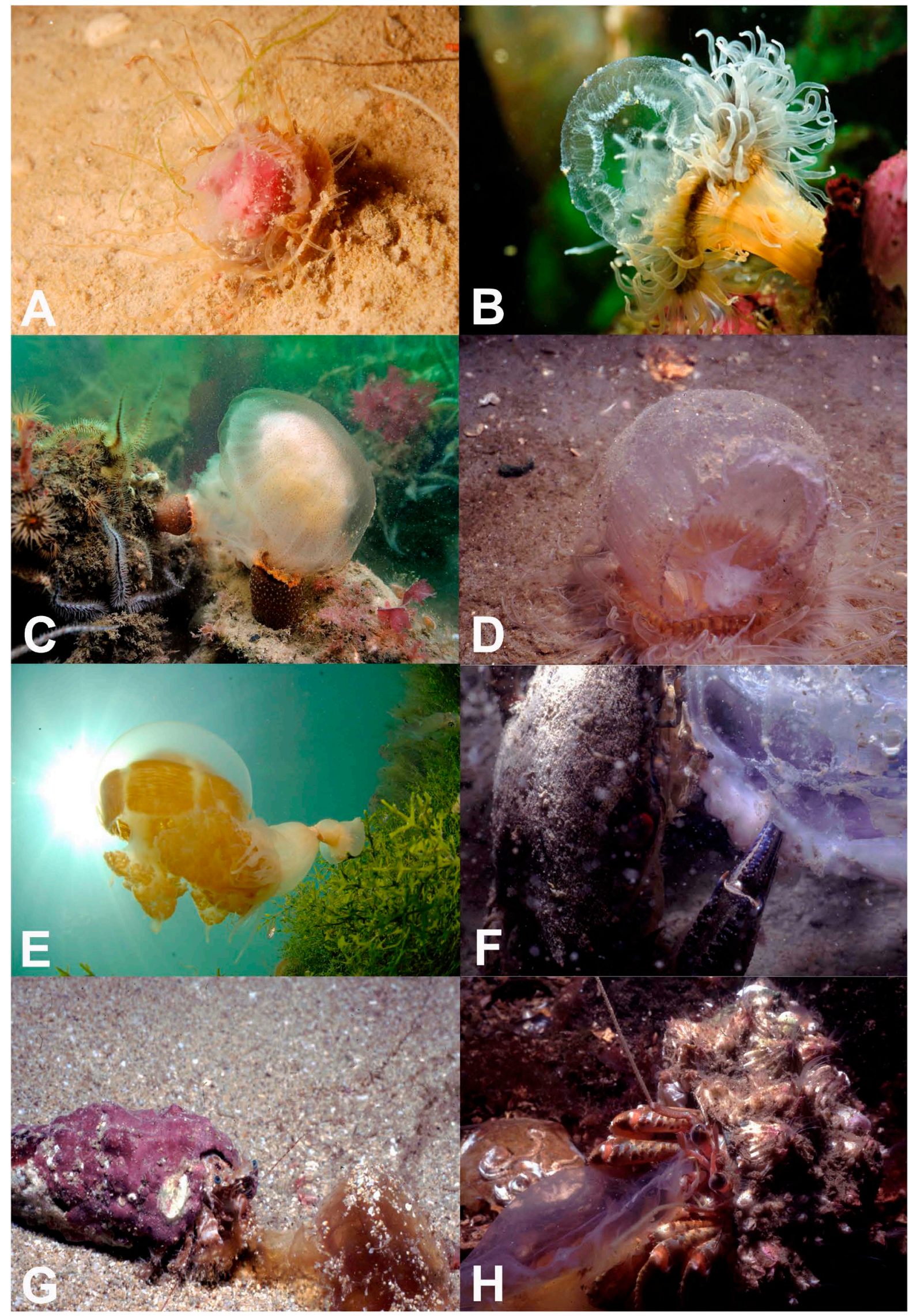

Plate 1. 
offered a jellyfish, in an experimental context under water, a sea anemone will rarely fail to grab and devour it. In deeper water beyond the reach of scuba-divers, sea anemones are also known to prey heavily on jellyfish (Jarms \& Tiemann 2004). As described by Jarms \& Tiemann (2004), jellyfish well exceeding the size of the oral disc of the sea anemone may be ingested as a result of a considerable inflation of its mouth and its oral disc. In shallow water this is exactly the same (see e.g. Ates 2002 and S. Daly in Wood 2013).

Predation upon jellyfish by decapod crabs is equally widespread (Table 1). None of the records seem to indicate that decapod crabs first attack the gonads, the most nutritious part of the jellyfish (cf. Rasmussen 1973). Contrary to sea anemones, decapod crabs may be able to actively pursue jellyfish as has been reported by Esser et al. (2004) for Pagurus bernhardus jumping up to capture $P$. pileus from the water column. Decapod crabs also are able to protect and defend their jellyfish prey, e.g. by moving away from a disturbance with it. This has been documented for Callinectes sapidus by Farr (1978) and for Hyas araneus by Ates \& Hoyinck (2012). Farr (1978) suggested that crabs may only prey on jellyfish in the absence of other prey. However, I can testify that in the majority of cases witnessed by me (see Table 1) other prey items were available, sometimes abundantly. It is not easy to have decapod crabs accept a jellyfish prey in situ as they are easily disturbed by the presence of a diver contrary to sea anemones. In cases where such an experiment succeeds, most crab species grab and eat the jellyfish.

Echinoderms have rarely been mentioned as scavengers of jellyfish. There can however be no doubt that Ophiocomina nigra plays an important role as such (Ates \& Hoyinck 2012). During three dives in Loch Sunart (Scotland) Ates \& Hoyinck (2012) observed at least twelve dead specimens of A. aurita in various stages of consumption by $O$. nigra and to a lesser extent by Asterias rubens and Ophiothrix gracilis. The jellyfish was always consumed from the outside in, leaving the highest part of the velum to be eaten last. There is no indication that echinoderm scavengers go for the gonads first, if these are present.

As jellyfish often occur in swarms, their simultaneous death may lead to a high number of jellyfish carcasses raining down on the sea floor in a limited period of time at certain locations. In the last decade this has led to an increased interest in the impact of jellyfish carcasses on deep-sea ecology (e.g. Lebrato et al. 2012). Yamamoto et al. (2008) implicated one sea anemone, two decapod, one gastropod and one ophiurid species to be scavengers of Nemopilema nomurai carcasses in deep water of the Sea of Japan. In their experiments in a deep Norwegian fiord Sweetman et al. (2014) found evidence of scavenging by hagfish and some species of small crustaceans in high numbers consuming jellyfish carcasses in a matter of hours. If a high number of dead jellyfish fall down in a very short time scavengers may be too few to deal with their remains, as has been documented by Billett et al. (2006) and Lebrato et al. (2012). Billett et al. (2006) did not investigate the diet of the spider crab Encephaloides armstrongi Woodmason present in large numbers as can be seen on their picture 3A. Elsewhere spider crabs are known as predators or scavengers of jellyfish, see Table 1.

Incidentally some of the records of predation on jellyfish mentioned in the introduction relate to non-pelagic fishes. Luttenberger (1981), Chaves et al. (2010), Thaler (2012) and Dias \& Almeida (2015) reported about coral reef fishes (e.g. species of Chaetodon, Zebrasoma, Pomacanthus and Naso) in different parts of the world benefitting from the influx of jellyfish into their realm. All these authors described the events as feeding frenzies, leading to the (near-)annihilation of the jellyfishes. This and my list of benthic invertebrate predators and scavengers (Table 1) contradicts the notion that "jellyfish are not readily consumed by other predators" (Condon et al. 2011). Quite the opposite may occur when jellyfish hit the coast or the sea floor. No barrier seems to exist for many benthic animals to consume dead or live jellyfish with relish. I have no doubt that proper fieldwork will reveal that jellyfish are being consumed by many more benthic scavengers and predators other than those contained in Table 1.

\section{Plate 1.}

A. Cerianthus lloydii (Cnidaria: Anthozoa: Ceriantharia) engulfing Neoturris cf pileata measuring less than $1.5 \mathrm{~cm}$ in diameter. Depth about $7 \mathrm{~m}$. Picture taken on June 27, 2012 on the Lochaline Wall (Sound of Mull, Scotland) by R. M. L. Ates.

B. A young Aurelia aurita measuring about $3 \mathrm{~cm}$ in diameter being taken by an immature Metridium senile in Dutch coastal waters. Depth unknown. Picture taken by R. Offermans on April 9, 2011.

C. Two Sagartia elegans holding one Chrysaora hysoscella. Diameter of the sea anemones between 3 and $4 \mathrm{~cm}$. Depth about $5 \mathrm{~m}$. Picture taken by R. Offermans in the Oosterschelde estuary, southwestern Netherlands on July 17, 2015.

D. Sagartiogeton undatus caught in the act of engulfing Aequorea vitrina, diameter about $5 \mathrm{~cm}$. Depth about $10 \mathrm{~m}$. Picture taken by R. M. L. Ates in July, 2005 in the Grevelingen, southwestern Netherlands.

E. Unknown sea anemone consuming Mastigias sp. in Lake Kakaban, Kalimantan, Indonesia. Column height of the sea anemone about $5 \mathrm{~cm}$. Depth unknown. Picture taken on October 2, 2010. Courtesy H. van Rijn.

F. Necora puber eating Cyanea lamarckii, diameter less than $10 \mathrm{~cm}$. Depth about $7 \mathrm{~m}$. Picture taken in the Oosterschelde, Netherlands in August 2003 by R. M. L. Ates.

G. Large numbers of Pelagia noctiluca may perish after entering Mgar-Ix-Ieni, Gozo, Malta due to southern winds. Their carcasses, less than $5 \mathrm{~cm}$ in length, are consumed by e.g. Pagurus anachoretus. Depth about $12 \mathrm{~m}$. Picture taken in October 2002 by R. M. L. Ates.

H. This mature Pagurus bernhardus is halfway through processing an Aurelia aurita. Depth about 3 m. Picture taken in June 2003 in Loch Fyne, Scotland by R. M. L. Ates. 
In her discussion Arai (2005) expressed the hope that awareness of the predation on jellyfish would lead to more knowledge of their role in pelagic food webs. Likewise I express the hope that this awareness will be extended to the benthic domain where many potential predators and scavengers await live or dead jellyfish coming within their reaches.

\section{Acknowledgements}

I thank Jos Bakker, Rick Harbo, Andy Lamb, Pat Lovejoy, Claudia Mills, Wendy Northway, Ron Offermans, Hans van Rijn and Mat Vestjens for sharing their observations. Additionally I thank Ron Offermans and Hans van Rijn for permission to use their photographs.

\section{References}

Alamaru A, Bronstein O, Loya Y, Dishon G (2009) Opportunistic feeding by the fungiid coral Fungia scruposa on the moon jellyfish Aurelia aurita. Coral Reefs 28: 865 .

Arai MN (1988) Interactions of fish and pelagic coelenterates. Can J Zool 66: 1913-1927.

Arai MN (2005) Predation on pelagic coelenterates: a review. J Mar Biol Ass UK 85: 523-536.

Ates RML (1988) Medusivorous fishes, a review. Zool Meded Leiden 62: $29-42$.

Ates RML (1991) Predation on Cnidaria by vertebrates other than fishes. Hydrobiol 216/217: 305-307.

Ates RML (2002) Kwallen als voedsel van zeeanemonen en van stormvogels. Zeepaard 62: 132-135.

Ates RML (2014) Nieuwe waarnemingen van Eutonina indicans (Romanes, 1876) in Nederland. Zeepaard 74: 157-161.

Ates RML, Hoyinck SEC (2012) Schijfkwallen in de voedselketen. Zeepaard 72: 126-131.

Ayre DJ (1984) The sea anemone, Actinia tenebrosa: an opportunistic insectivore. Ophelia 23: 149-153.

Bamstedt U, Ishii H, Martinussen B (1997) Is the scyphomedusa Cyanea capillata $(\mathrm{L}$.) dependent on gelatinous prey for its early development? Sarsia 82: 269-273.

Battaglia P, Musolino S, Esposito V, Ammendolia G, Consolia P, Andaloro F, Romeo T (2014) Feeding habits of juvenile fishes belonging to three medusivorous species (Centrolophidae and Nomeidae) from the Strait of Messina (central Mediterranean Sea). Mar Biol Res 10: 927-933.

Bayha KM, Graham WM, Higgins JE, Fletcher HA (2012) Predation potential of the jellyfish Drymonema larsoni Bayha \& Dawson (Scyphozoa: Drymonematidae) on the moon jellyfish Aurelia sp in the northern Gulf of Mexico. Hydrobiol 690: 189-197.

Bell J (1996) Fulmars feeding on jellyfish. Brit Birds 89: 569.

Berryman J (1984) Predation of Sagartiogeton laceratus upon Aurelia aurita in shallow water. J Mar Biol Ass UK 64: 725.

Billett DSM, Bett BJ, Jacobs CL, Rouse IP, Wigham BD (2006) Mass deposition of jellyfish in the deep Arabian Sea. Limnol Oceanogr 51: 2077-2083.

Bonaldo RM, Krajewski JP, Sazima I (2004) Does the association of young fishes with jellyfishes protect from predation? A report on a failure case due to damage to the jellyfish. Neotrop Ichthyol 2: 103105.

Cardona L, Álvarez de Quevedo I, Borrell A, Aguilar A (2012) Massive consumption of gelatinous plankton by Mediterranean apex predators. PloS ONE 7(3): e31329.

Cargo DG, Schultz LP (1967) Further observations on the biology of the sea nettle and jellyfishes in Chesapeake Bay. Chesap Sci 8(4):
209-220.

Chaves LCT, Feitosa JLL, Pereira PHC (2010) First record of predation on jellyfish by butterflyfish on Brazilian rocky reefs. Mar Biodiv Rec 3: $3 \mathrm{pp}$.

Cerqueira VR, Haimovici M (1990) Dinamica populacional do gordinho, Peprilus parua, no litoral sul do Brasil. Rev Brasil Biol 50: 599-613.

Condon RH, Steinberg DK, Giorgio PA Del, Bouvier TC, Bronk DA, Graham WM, Ducklow HW (2011) Jellyfish blooms result in a major microbial respiratory sink of carbon in marine systems. Proc Nat Acad Sci USA 108: 10225-10230.

Cones HN, Haven DS (1969) Distribution of Chrysaora quinquecirrha in the York River. Chesap Sci 10: 75-84.

Conniff R (2000) Jelly bellies. Nat Geogr Mag 197(6): 82-101.

Corsi F (2000) Inconsueta alimentazione del gabbiano reale mediterraneo Larus cachinnans michahelis. Picus 27: 99.

Dathe H (1989) Zur Ernährung heimischer Möwen. Ornith Mitt 41: 15.

Dayton PK, Robilliard GA, Paine RT, Dayton LB (1974) Biological accomodation in the benthic community at McMurdo Sound, Antarctica. Ecol Monogr 44: 105-128.

Dias RM, Almeida DF (2015) First record of predation on jellyfish by an aggregation of French angelfish Pomacanthus paru on Brazilian rocky reefs. Mar Biodiv Rec 8: 3 pp.

Esser M, Greve W, Boersma M (2004) Effects of temperature and the presence of benthic predators on the vertical distribution of the ctenophore Pleurobrachia pileus. Mar Biol 145: 595-601.

Farr JA (1978) Blue crab predation on jellyfish. Florida Sci 41: 217-218.

Fautin DG (1982) Paraphelliactis pabista, a new species of hormathiid sea anemone from abyssal northeastern Pacific waters. Syesis 15: $51-56$.

Fautin DG, Fitt WK (1991) A jellyfish-eating sea anemone from Palau: Entacmaea medusivora. Hydrobiol 216/217: 453-461.

Francis L (1973) Intraspecific aggression and its effect on the distribution of Anthopleura elegantissima and some related sea anemones. Biol Bull 144: 73-92.

Gili JM, Hughes RG, Alva V (1996) A quantitative study of feeding by the hydroid Tubularia larynx. Sci Mar 60: 43-54.

Gorelova T, Grudtsev ME (1986). Feeding of flying fishes in the Atlantic ocean. Okeanologiya 27: 480-483.

Greve W (1972) Ökologische Untersuchungen an Pleurobrachia pileus. Helgol wiss Meeresunters 23: 141-164.

Gronert R (1992) Soms is een kwal om op te vreten. Windbreker 52: 9 \& 53: 19.

Hall H (1992) High seas' drifter. Nat Hist 1992(12): 26-29.

Hamner WM (1982) Strange world of Palau's salt lakes. Nat Geogr Mag 161: 264-282.

Hamner WM, Hauri IR (1981) Long-distance horizontal migrations of zooplankton (Scyphomedusae: Mastigias). Limnol Oceanogr 26: 414423.

Harbison GR (1993) The potential of fishes for the control of gelatinous zooplankton. ICES (Int Counc Explor Sea) CMS (1993/L:74): 1-10.

Harbo RM (2011) Whelks to whales: coastal marine life of the Pacific Northwest. Harbour Publishing Co Ltd, Madeira Park, BC, Canada, $328 \mathrm{pp}$.

Hartog JC den (1963) De verspreiding van Tealia felina, de zeedahlia, in Nederland. Zeepaard 23: 75-82.

Hoeksema BW, Tuti Y, Becking LE (2015) Mixed medusivory by the sea anemone Entacmaea medusivora (Anthozoa: Actiniaria) in Kakaban Lake, Indonesia. Mar Biodivers 45: 141-142.

Jarman SN, McInnes J, Faux C, Polanowski AM, Marthick J, Deagle BE, Southwell C, Emmerson L (2013) Adélie pinguin population diet monitoring by analysis of food DNA in scats. PloS ONE 8(12): 11 pp.

Jarms G, Tiemann H (2004) Actinostola callosa, a medusivorous sea anemone and its mass occurrence in the Lurefjord, Norway. Helgol Mar Res 58: 15-17.

Jones TT, Seminoff JA (2013) Feeding biology, Advances from fieldbased observations, physiological studies, and molecular techniques. In: The Biology of Sea Turtles III (eds Wyneken J, Lohmann KJ, 
Musick JA). CRC Press, Boca Raton London New York, pp. 211-247.

Kelley DF (1987) Food of bass in U.K. waters. J Mar Biol Ass UK 67: 275-286.

Larson RJ (1991) Why jellyfish stick together. Nat Hist 100: 66-71.

Lauckner G (1980) Diseases of Cnidaria. In: Diseases of Marine Animals (ed Kinne O). John Wiley \& Sons, Chichester New York Brisbane Toronto, pp. 167-237.

Lebrato M, Pitt KA, Sweetman KA, Jones DOB, Cartes JE, Oschlies A, Condon RH, Molinero JC, Adler L, Gaillard C, Loris D, Billett DSM (2012) Jelly-falls historic and recent observations: a review to drive future research directions. Hydrobiol 690: 227-245.

Luttenberger F (1981) Nahrungsgewohnheiten einiger Fische in Korallenriffen des Roten Meeres. Aquar Terr Zeitschr (DATZ) 34(4): 131134.

Mackie GO (1966) Growth of the hydroid Tubularia in culture. In: The Cnidaria and Their Evolution (ed Rees WJ). Academic Press, New York, pp. 397-410.

Massuti E, Deudero S, Sanchez P, Morales-Nin B (1998) Diet and feeding of dolphin (Coryphaena hippurus) in western Mediterranean waters. Bull Mar Sci 63: 329-341.

Melville DS (2013) Variable (Haematopus unicolor) and pied oystercatchers (H. finschi) feeding on lion's mane jellyfish (Cyanea sp.). Notorchis 60: 309-310.

Milisenda G, Rosa S, Fuentes VL, Boero F, Guglielmo L, Purcell JE, Piraino $S$ (2014) Jellyfish as prey: frequency of predation and selective foraging of Boops boops (Vertebrata, Actinopterygii) on the mauve stinger Pelagia noctiluca (Cnidaria, Scyphozoa). PLoS ONE 9(4): 10 pp.

Miyake H, Lindsay DJ, Hunt JC, Hamatsu T (2002) Scyphomedusa $A u$ relia limbata (Brandt, 1838) found in deep waters off Kushiro, Hokkaido, northern Japan. Plankton Biol Ecol 49: 44-46.

Moen FE, Svensen E (2000) Dyreliv i havet, handbok i Norsk marin fauna. KOM Forlag, Kristiansand, 2nd ed, pp. 1-608.

Naylor P (2011) Great British Marine Animals. Sound Diving Publ, Plymouth, UK, 3rd ed, 320 pp.

Orsi Relini L, Garibaldi F, Lanteri L, Relini M (2010a) Medusivorous fishes of the Ligurian sea 1. Chub mackerels and other pelagic fish species sometimes have the medusa Pelagia noctiluca. Rapp Comm int Mer Médit 39: 62.

Orsi Relini L, Lanteri L, Garibaldi F (2010b) Medusivorous fishes of the Mediterranean. A coastal safety system against jellyfish blooms. Biol Mar Mediterr 17: 348-349.

Peglow HG (1998) Quallengonaden als Silbermöwennahrung. Ornith Mitt 50: 124.

Phillips PJ, Burke WD, Keener EJ (1969) Observations on the trophic significance of jellyfishes in Mississippi Sound with quantitative data on the associative behavior of small fish. Trans Am Fish Soc 1969(4): 703-712.

Powell EH, Gunter G (1968) Observations on the stone crab Menippe mercenaria in the vicinity of Port Aransas, Texas. Gulf Res Rep 2:
285-299.

Purcell JE (1991) A review of cnidarians and ctenophores feeding on competitors in the plankton. Hydrobiol 216/217: 335-342.

Purcell JE, Arai MN (2001) Interactions of pelagic cnidarians and ctenophores with fish: a review. Hydrobiol 451: 27-44.

Quilter CG (1987) Foraging activity of the sand beach isopod Scyphax ornatus. New Zeal J Zool 14: 433-439.

Rainer SF (1992) Diet of prawns from the continental slope of northwestern Australia. Bull Mar Sci 50: 258-274.

Rasmussen E (1973) Systematics and ecology of the Isefjord marine fauna. Ophelia 11: 1-495.

Redeke HC (1911) Natuurlijke historie onzer zeevisschen een handleiding ten gebruike bij het visscherij-onderwijs. C. de Boer, Den Helder, Nederland, $92 \mathrm{pp}$.

Sebens KP, Koehl MAR (1984) Predation on zooplankton by the benthic anthozoans Alcyonium siderium and Metridium senile in the New England subtidal. Mar Biol 81: 255-271.

Shiomi K, Ogi H (1992) Feeding ecology and body size dependence on diet of the sooty shearwater, Puffinus griseus, in the north Pacific. Proc Nat Inst Polar Res Symp on Polar Biol 5: 105-113.

Steinich M (1973) Unterwasser-Blitztechnik. Foto-Magazin 25: 38-39.

Stoner EW, Layman CA (2015) Bristle worms attack: benthic jellyfish are not trophic dead ends. Front Ecol Env 13: 226-227.

Suazo CG (2008) Black-browed albatross foraging on jellyfish prey in the southeast Pacific coast, southern Chile. Polar Biol 31: 755-757.

Sweetman AK, Smith CR, Dale T, Jones DOB (2014) Rapid scavenging of jellyfish carcasses reveals the importance of gelatinous material to deep-sea food webs. Proc R Soc B 281: 1-8.

Swennen C (1956) Kwallen in gevangenschap. Zeepaard 16: 35-39.

Thaler E (2012) Eine Qualle für alle! Ungewöhnliche Tischgesellschaften im Meer. Koralle 13(4): 78-81.

Thomas LR (1963) Phyllosoma larvae associated with medusae. Nature 198: 208.

Vlugt PJ van der (1981) Actinoporus elegans. Zeeaquarium 31(5): 5-9.

Wertheim A (1984) The Intertidal Wilderness. Sierra Club Books, San Francisco, $156 \mathrm{pp}$.

Wood C (2005) Seasearch Guide to Sea Anemones and Corals of Britain and Ireland. Marine Conservation Society, Ross-on-Wye, 128 pp.

Wood C (2013) Sea Anemones and Corals of Britain and Ireland. Wild Nature Press, Plymouth, UK, $160 \mathrm{pp}$.

Wu N (1998) Splendors of the Seas: The Photographs of Norbert Wu, Konemann UK Ltd, London, $252 \mathrm{pp}$.

Yamamoto J, Hirose M, Ohtani T, Sugimoto K, Hirase K, Shimamoto N, Shimura T, Honda N, Fujimori Y, Mukai T (2008) Transportation of organic matter to the sea floor by carrion falls of the giant jellyfish Nemopilema nomurai in the Sea of Japan. Mar Biol 153: 311-317.

Zann LP (1988) Marine Community Aquarium. TFH Publications, Neptune City, NJ 07783, 416 pp.

Zonfrillo B (1997) Fulmars feeding on jellyfish and their parasites. Brit Birds 90: 293. 